\title{
PENGARUH MODEL PEMBELAJARAN CTL BERBANTUAN TTS TERHADAP HASIL BELAJAR KIMIA
}

\section{THE EFFECT OF LEARNING MODELS CTL ASSISTED BY CROSSWORD PUZZLE ON CHEMISTRY LEARNING OUTCOMES}

\author{
Henie Poerwandar Asmaningrum ${ }^{1, *}$, Joice Bunga $^{1}$, Inggrid Marlissa ${ }^{2}$ \\ ${ }^{1}$ Jurusan Pendidikan Kimia FKIP Universitas Musamus \\ Jln. Kamizaun, Mopah Lama, Merauke, 99610 \\ ${ }^{2}$ Jurusan Pendidikan Matematika FKIP Universitas Musamus \\ Jn. Kamizaun, Mopah Lama, Merauke, 99610 \\ *e-mail korespondensi: poerwandar@unmus.ac.id
}

\begin{abstract}
Abstrak
Penelitian ini bertujuan untuk mendeskripsikan pengaruh penerapan model pembelajaran Contextual Teaching and Learning (CTL) berbantuan Teka-Teki Silang (TTS) terhadap hasil belajar kimia. Jenis penelitian ini adalah penelitian eksperimen dengan one group pretest posttest design. Sampel penelitian ini adalah mahasiswa Jurusan Pendidikan Kimia yang mengambil mata kuliah biokimia, yang terdiri dari 13 orang. Analisis data menggunakan paired sample t-test. Hasil penelitian diperoleh $\mathrm{t}_{\text {hit }}=7,27$ lebih besar dari nilai $\mathrm{t}_{\text {tabel }}=1,78$ yang berarti bahwa $\mathrm{H}_{0}$ ditolak dan $\mathrm{H}_{\mathrm{a}}$ diterima, sehingga dapat disimpulkan bahwa terdapat pengaruh model pembelajaran CTL berbantuan TTS terhadap hasil belajar kimia.
\end{abstract}

Kata kunci: Contextual Teaching and Learning (CTL), Teka-Teki Silang (TTS), hasil belajar

\begin{abstract}
This study aims to describe the effect of CTL learning model application assisted by crossword puzzle (TTS) on the learning outcomes of chemistry. This type of research is an experimental study with one group pretest posttest design. The sample of this study were students of the Department of Chemistry Education who took biochemistry courses, consisting of 13 people. Data analysis using independent sample $t$-test. The results were obtained $t_{\text {hit }}=7.27$ greater than the value of $t_{\text {table }}=1.78$ which means that $\mathrm{H}_{0}$ is rejected and $\mathrm{H}_{\mathrm{a}}$ is accepted, so it can be concluded that there is an influence of the CTL learning model assisted by crossword puzzle (TTS) towards chemistry learning outcomes.
\end{abstract}

Keywords: Contextual Teaching and Learning (CTL), crossword puzzle, learning outcomes

\section{PENDAHULUAN}

Perkembangan ilmu pengetahuan dan teknologi menuntut peningkatan mutu pendidikan. Pengaruh berkembangnya ilmu pengetahuan dan teknologi dalam sektor pembangunan sangat luas. Pendidikan berperan untuk menyiapkan sumberdaya manusia yang mampu berpikir secara mandiri dan kritis, karena pendidikan merupakan modal dasar bagi pembangunan manusia yang berkualitas (Prasetyaningrum, 2013). Pendidikan merupakan sarana utama dalam upaya meningkatkan kualitas sumber daya manusia. Penyelenggaraan pendidikan diharapkan dapat membekali manusia dengan pengetahuan, kecakapan, dan keterampilan (Umar, 2013). Tanpa pendidikan akan sulit diperoleh hasil dari kualitas sumber daya manusia yang maksimal. Di jaman sekarang ini masalah pendidikan menjadi hal yang penting, terutama bagi bangsa Indonesia dalam mencapai tujuan pendidikan nasional, yaitu pencapaian sumber daya manusia yang berkualitas dan mampu bersaing di tingkat global. 
Menurut Undang-Undang No. 20 Tahun 2013 tentang Sistem Pendidikan Nasional (UU Sisdiknas), pembelajaran adalah proses interaksi peserta didik dengan pendidik dan sumber belajar pada suatu lingkungan belajar. Keberhasilan proses pembelajaran merupakan hal utama yang diharapkan dalam melaksanakan suatu pendidikan. Dalam proses pembelajaran, komponen utama adalah pendidik dan peserta didik. Dalam hal ini pendidik memiliki pola pembelajaran yang berbeda-beda yang disebut dengan model pembelajaran. Proses pembelajaran yang dimaksud adalah suatu perubahan yang terjadi melalui latihan atau pengalaman, dalam arti perubahan-perubahan yang disebabkan oleh pertumbuhan atau kematangan tidak dianggap sebagai hasil belajar, seperti perubahan-perubahan yang terjadi pada diri seorang bayi (Purwanto, 2010).

Pembelajaran merupakan upaya atau cara pendidik melakukan kegiatan belajar, yang bertujuan untuk mewujudkan efisiensi dan efektifitas kegiatan belajar (Isjoni, 2007). Pembelajaran merupakan suatu sistem yang terdiri dari berbagai komponen yang saling berhubungan satu dengan yang lain.

Supaya pembelajaran efektif, pendidik perlu mempelajari suatu model kognitif, dengan maksud peserta didik ataupun pendidik secara bersamaan mempunyai hubungan timbal balik. Hal ini memampukan pendidik untuk menata pembelajaran peserta didiknya dan mengajarkan cara memecahkan masalah atas dorongan dari dalam diri mereka sendiri. Secara hakiki, kegiatan ini bersifat mengkonsolidasikan dan mempromosikan praktik latihan, dan pengulangan sehingga memungkinkan peserta didik untuk menjalani pembelajaran baru melalui proses akomodasi yang mengakibatkan pengubahan atau perluasan struktur kognitif. Teori Konstruktiv Piaget dicirikan oleh pembelajaran aktif, pengalaman langsung dan motivasi intrinsik yang memacu perkembangan kognitif.

Dalam dunia pendidikan ilmu kimia memiliki peran penting yang berkaitan dengan cara mencari tahu tentang alam secara sistematis, penguasaan kumpulan pengetahuan yang berupa fakta-fakta, konsep-konsep atau prinsip-prinsip serta merupakan suatu proses penemuan. Kimia merupakan bagian dari ilmu pengetahuan alam yang sering dikatakan sukar untuk dimengerti dan dipelajari, sehingga untuk memberikan pemahaman konsep maka harus diberikan suatu cara atau metode dan media yang tepat yang diberikan terhadap peserta didik.

Berdasarkan observasi, masalah yang sering muncul pada saat pembelajaran berlangsung khususnya pembelajaran kimia adalah: (1) peserta didik pasif, (2) peserta didik mengalami kesulitan dalam memahami konsep kimia, (3) pendidik bersifat teacher center dan (4) peserta didik kurang fokus dalam pembelajaran. Hal ini dapat dilihat dari hasil UTS mahasiswa semester 3 sebelumnya yang mendapatkan nilai dibawah 70. Permasalahanpermasalahan yang terjadi di dalam kelas inilah yang diduga menjadi penyebab rendahnya hasil belajar peserta didik. Hasil belajar yang rendah akan mempengaruhi kelulusan dan berdampak buruk terhadap prestasi dan nilai peserta didik.

Salah satu alternatif untuk mengatasi permasalahan tersebut adalah menggunakan model pembelajaran kooperatif. Menurut (Purnamasari, 2013), pembelajaran kooperatif merupakan kemandirian belajar pembelajaran kelompok yang diorganisir oleh satu prinsip bahwa pembelajaran harus didasarkan pada perubahan informasi secara sosial di antara kelompok-kelompok pembelajarnya yang di dalamnya setiap pembelajaran bertanggung jawab sendiri dan didorong untuk meningkatkan pembelajaran anggota-anggota yang lain. Pembelajaran kooperatif dengan sains dipandang sebagai penyatu alamiah yang bersifat kontekstual oleh banyak guru sains. Pembelajaran dengan sains yang berkaitan dengan kehidupan sekitar. "Contextual teaching is teaching that enables learning in which students have their academic understanding and abilities in a variety of in and out of school context to solve simulated or real world problems, both alone and with others" artinya CTL adalah pembelajaran yang memungkinkan terjadinya proses belajar dimana siswa menggunakan pemahaman dan kemampuan akademiknya dalam berbagai konteks dalam dan luar sekolah untuk memecahkan masalah yang bersifat simulatif ataupun nyata, baik sendirisendiri maupun bersama-sama (Rusman, 2011).

Terdapat beberapa karateristik pembelajaran kontekstual, yaitu melakukan hubungan yang bermakna (making meaningfull connection), melakukan kegiatan-kegiatan yang signifikan (doing significant work), belajar yang diatur sendiri (self-regulated learning), bekerjasama (collaborating), berpikir kritis dan kreatif (critical and creative thinking), mengasuh dan memelihara pribadi siswa 
(nurturing the individual), mencapai standar yang tinggi (reaching high standar), menggunakan penelitian autentik (using authentic assessment). Terdapat 7 (tujuh) komponen pembelajaran kontekstual, yaitu: konstruktivisme (constructivism), bertanya (questioning), menemukan (inquiry), masyarakat belajar (learning community), pemodelan (modelling), refleksi (reflection), dan penilaian sebenarnya (authentic assessment).

Dalam pembelajaran CTL mahasiswa harus berperan aktif dalam pembelajaran untuk menemukan suatu materi kemudian menghubungkannya dengan kondisi kehidupan di sekitar. Pembelajaran CTL menekankan pada berfikir tingkat tinggi, transfer pengetahuan lintas disiplin, serta pengumpulan, penganalisaan dan pensintesisan informasi dan data dari berbagai sumber dan pandangan (Sanjaya, 2010).

Penggunaan media pembelajaran sangat membantu guru mengembangkan dan memperdalam proses belajar mengajar di kelas. Penggunaan media pembelajaran yang bervariasi dengan tepat dapat mempengaruhi aktivitas, minat dan motivasi belajar siswa yang tentunya akan mempengaruhi prestasi belajarnya. Zaini (2008) menyatakan bahwa TTS dapat digunakan sebagai media pembelajaran yang baik dan menyenangkan tanpa meninggalkan esensi belajar yang sedang berlangsung.

Menurut (Asmaningrum, 2017) TTS adalah susunan kotak-kotak yang diberi nomor yang diisi dengan kata-kata, setiap kotak diisi satu huruf sehingga membentuk suatu kata yang ditempatkan secara horizontal dan vertikal. Sejalan dengan Claire yang mengatakan bahwa sebuah teka-teki kata dalam kotak hitam dan putih yang berbentuk persegi yang tujuannya untuk menulis satu huruf disetiap persegi putih untuk membuat kata-kata dengan diberikan petunjuk pertanyaan. Kotak hitam menandakan dimana kata berakhir (Claire, 2010).

Media pembelajaran TTS memiliki manfaat (Karyos dan Nia, 2012) antara lain:

1) Menyenangkan

2) Membangun minat membaca dan menulis

3) Membangun kosa kata

4) Membangun konsentrasi

5) Membantu mahasiswa dalam belajar

6) Membentuk disiplin diri

7) Mendorong mahasiswa bereksplorasi

8) Membangkitkan rasa ingin tahu

Berdasarkan uraian tersebut maka penelitian ini bertujuan untuk mengetahui pengaruh model pembelajaran CTL berbantuan TTS terhadap hasil belajar kimia.

\section{METODE PENELITIAN}

Jenis penelitian yang digunakan dalam penelitian ini adalah penelitian komparatif dengan pendekatan eksperimen. Penelitian ini menggunakan bentuk desain eksperimen One Group Pretest Posttest Design, terdiri dari empat kali pertemuan.

Penelitian ini dilaksanakan di Jurusan Pendidikan Kimia Fakultas Keguruan dan Ilmu Pendidikan (FKIP) Universitas Musamus Merauke pada bulan Oktober semester ganjil tahun pelajaran 2017/2018. Populasi berjumlah 30 mahasiswa. Sampel berjumlah 13 mahasiswa.

Variabel dalam penelitian ini meliputi variabel bebas yaitu model pembelajaran CTL berbantuan TTS. Variabel terikat yaitu hasil belajar kimia. Teknik dan instrumen pengumpulan data diambil menggunakan tes berupa soal uraian yang terdiri dari 5 soal.

Uji validitas menggunakan validitas rupa. Validitas rupa (face validity) adalah validitas yang menunjukkan apakah alat pengukur/instrumen penelitian dari segi rupanya tampak mengukur apa yang ingin diukur, validitas ini lebih mengacu pada bentuk dan penampilan instrumen. . Hasil uji validitas rupa diperoleh kesepakatan antara dua pengamat yang sama. Hal ini menunjukkan konsistensi antara dua pengamat sangat baik (Sugiyono, 2016).

Teknik analisis data yang digunakan adalah statistik inferensial.

1. N-gain

Data utama yang digunakan untuk melihat peningkatan hasil belajar adalah data hasil pretest dan posttest. Data tersebut kemudian dihitung menggunakan rumus N-Gain. Rumus $\mathrm{N}$-Gain adalah sebagai berikut (Jumiati, 2011) :

$$
N-\operatorname{Gain}(g)=\frac{\left(S_{\text {post }}\right)-\left(S_{\text {pre }}\right)}{\text { maks }-\left(S_{\text {pre }}\right)}
$$

Keterangan :

$$
\begin{array}{ll}
\mathrm{S}_{\text {post }} & =\text { Skor posttest } \\
\mathrm{S}_{\text {pre }} & =\text { Skor } \text { pretest }
\end{array}
$$

Kriteria perolehan skor N-Gain dapat dilihat pada Tabel 1. 
Tabel 1. Kategori Perolehan Skor N-Gain

\begin{tabular}{cc}
\hline Batasan & Kategori \\
\hline$(\mathrm{g}) \geq 0,7$ & Tinggi \\
$0,3 \leq(\mathrm{g})<0,7$ & Sedang \\
$(\mathrm{g})<0,3$ & Rendah \\
\hline
\end{tabular}

2. Uji Normalitas

Uji normalitas digunakan untuk mengetahui data berdistribusi normal atau tidak berdistribusi normal. Rumus yang digunakan adalah Chikuadrat .

Hipotesis statistik

$\mathrm{H}_{0}=$ Data berdistribusi normal

$\mathrm{H}_{\mathrm{a}}=$ Data tidak berdistribusi normal

Selanjutnya adalah statistik uji sebagai berikut (Sugiyono, 2016):

$$
\chi^{2}=\sum_{i=1}^{k} \frac{\left(f_{0}-f_{h}\right)^{2}}{f_{h}}
$$

Keterangan:

$\chi^{2}=$ Normalitas

$f_{0}=$ Frekuensi yang diobservasi

$f_{h}=$ Frekuensi yang diharapkan

Selanjutnya bandingkan $\chi^{2}$ hitung dengan $\chi^{2}$ tabel menggunakan tabel taraf signifikan sebesar $5 \%$. Kriteria pengujiannya adalah tolak $\mathrm{H}_{0}$ jika hitung $\chi_{\text {hitung }}^{2} \geq \chi_{\text {tabel, }}^{2}$ selain itu terima $\mathrm{H}_{0}$.

\section{Uji Hipotesis}

Uji hipotesis menggunakan rumus paired sample t-test 2 arah. Untuk keperluan pengujian secara statistik, maka rumusan hipotesis statistiknya sebagai berikut:

$\mathrm{H}_{0}=\mu_{\mathrm{g}}=0$

$\mathrm{H}_{\mathrm{a}}=\mu_{\mathrm{g}} \neq 0$

(Suharsaputra, 2014)

dimana:

$\mu_{\mathrm{g}}=\mu_{\mathrm{B}}-\mu_{\mathrm{A}}$

\section{Keterangan :}

$\mathrm{H}_{0}$ : artinya tidak terdapat pengaruh penerapan model pembelajaran CTL berbantuan TTS terhadap hasil belajar kimia

$\mathrm{H}_{\mathrm{a}}$ : artinya terdapat pengaruh penerapan model pembelajaran CTL berbantuan TTS terhadap hasil belajar kimia

$\mu_{\mathrm{A}}$ : parameter rata-rata skor hasil belajar kimia pretes

$\mu_{\mathrm{B}}$ : parameter rata-rata skor hasil belajar kimia postes

\section{HASIL DAN PEMBAHASAN}

Sebelum diterapkan model pembelajaran CTL pada mahasiswa dilakukan tes untuk mengetahui data awal prestasi belajar kimia mahasiswa. Penerapan model pembelajaran CTL diterapkan pada proses pembelajaran pertemuan berikutnya. Setelah pokok bahasan selesai, dilakukan postes untuk melihat pengaruh penerapan model pembelajaran CTL berbantuan TTS terhadap hasil belajar kimia. Ditinjau dari nilai rata-rata, hasil belajar mahasiswa ditunjukkan pada Tabel 2.

Tabel 2. Data Hasil Belajar Mahasiswa

\begin{tabular}{l|c|c}
\hline Uraian & Pretes & Postes \\
\hline Sampel & 13 & 13 \\
Nilai Ideal & 100 & 100 \\
Nilai Tertinggi & 60 & 100 \\
Nilai Terendah & 0 & 5 \\
Nilai Rata-Rata & 28,46 & 70 \\
\hline
\end{tabular}

Tabel 2 menunjukkan bahwa pada pretes diperoleh nilai rata-rata sebesar 28,46 dengan nilai tertinggi 60 dan nilai terendah 0 . Hal ini berarti bahwa mahasiswa masih belum memahami materi kimia lipid. Proses pembelajaran juga masih menggunakan model pembelajaran konvensional yang merupakan pembelajaran dengan berpusat pada pendidk dan dikarenakan mahasiswa belum memahami materi. Pembelajaran konvensional membuat mahasiswa cenderung diam karena malu untuk bertanya dan hanya mencatat apa yang telah dituliskan pendidik di papan tulis, sehingga pemahaman mahasiswa satu dengan lainnya menjadi berbeda.

Pada hasil postes diperoleh nilai rata-rata 70 dengan nilai tertinggi 100 dan nilai terendah 5. Model pembelajaran CTL berbantuan TTS terdapat unsur permainan yang membuat suasana pembelajaran menjadi lebih menyenangkan. Mahasiswa dibagi menjadi beberapa kelompok sehingga terjadi proses berpikir, kemudian mahasiswa berinteraksi dalam membahas isi dari hasil materi pembelajaran, dan dari hasil diskusi mahasiswa akan menuliskan jawaban atas soal yang diberikan dalam bentuk TTS.

Langkah-langkah yang dilakukan sesuai dengan sintaks pembelajaran kooperatif dan sintaks pembelajaran kontekstual (Rusman, 2011), yaitu menyiapkan materi, membagi mahasiswa menjadi beberapa kelompok, membagikan TTS kepada masing-masing kelompok, menjelaskan peraturan dan proses 
pembelajaran dengan model CTL berbantuan TTS, mengevaluasi materi dan teka-teki silang, memberikan penghargaan kepada pasangan kelompok yang mengerjakan paling cepat dan benar.

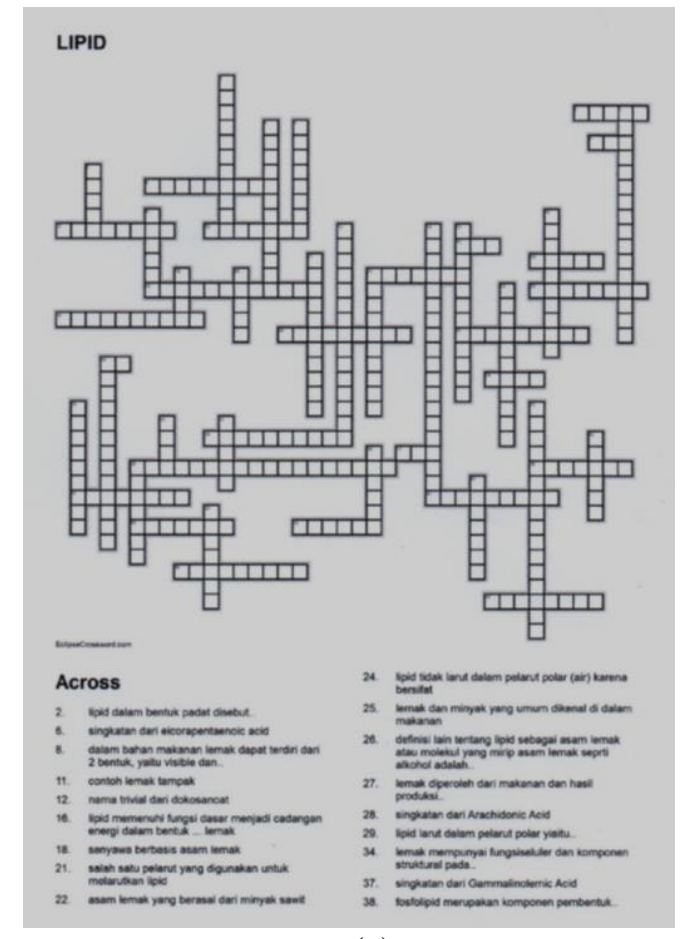

(a)

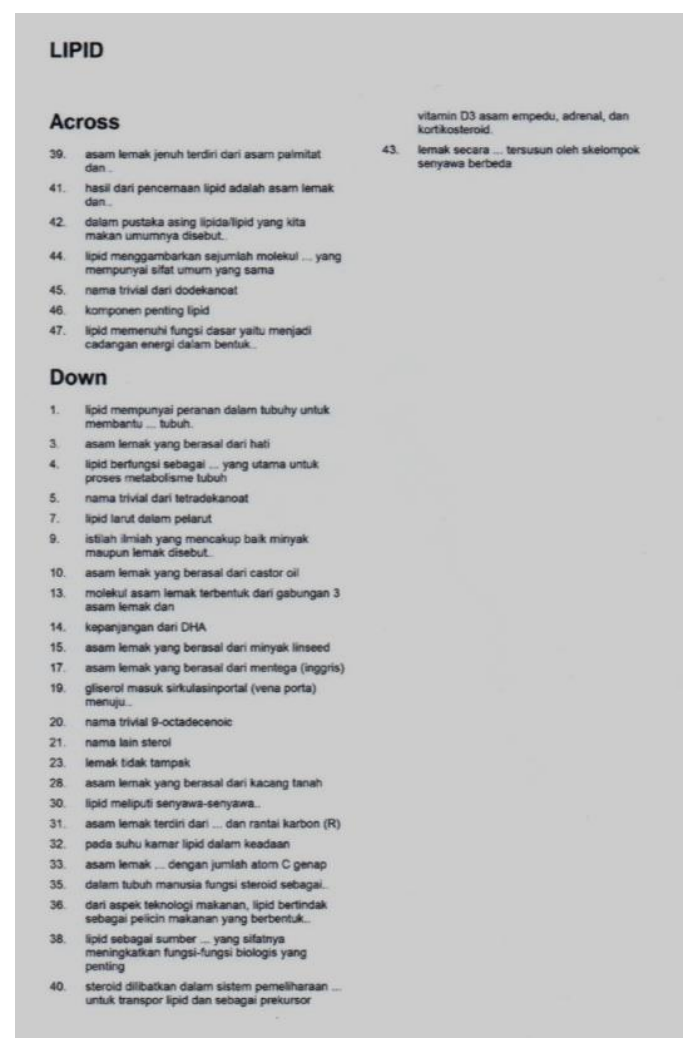

(b)

Gambar 1. Media TTS yang digunakan dalam pembelajaran (a) tampak depan (b) tampak belakang
Peningkatan hasil belajar mahasiswa dengan menerapkan model CTL menggunakan TTS ditandai dengan nilai rata-rata $\mathrm{N}$-Gain seperti ditunjukkan pada Tabel 3.

Tabel 3. Rekapitulasi N-Gain

\begin{tabular}{c|c|c|c|c}
\hline Data & Pretes & Postes & $\begin{array}{c}\text { Nilai } \\
\text { ideal }\end{array}$ & $\begin{array}{c}N \text { - } \\
\text { Gain }\end{array}$ \\
\hline $\begin{array}{l}\text { Rata- } \\
\text { rata }\end{array}$ & 28,4615 & 70 & 100 & 0,62 \\
\hline
\end{tabular}

Tabel 3 menunjukkan nilai $\mathrm{N}$-Gain sebesar 0,62 jika dikategorikan maka termasuk kategori tinggi. Hal ini berarti bahwa pemahaman mahasiswa pada materi lipid meningkat.

Sebelum melakukan uji hipotesis terlebih dahulu akan dilakukan uji asumsi yang harus dipenuhi yaitu uji normalitas dan uji homogenitas. Pengujian normalitas adalah uji yang dilakukan dengan membandingkan $\chi 2$ hitung dengan $\chi 2$ tabel dengan taraf signifikan sebesar 5\% dan derajat kebebasan (n-1). Adapun hasil perhitungan dapat dilihat dalam tabel 34.

Tabel 4. Data Hasil Perhitungan Normalitas

\begin{tabular}{c|c|c}
\hline Uraian & Pretes & Postes \\
\hline $\mathrm{N}$ & 13 & 13 \\
$\mathrm{~A}$ & 0,05 & 0,05 \\
$\chi^{2}{ }_{\text {hitung }}$ & 3,29 & 4,68 \\
$\chi_{\text {tabel }}^{2}$ & \multicolumn{2}{|c}{9,488} \\
Keterangan & Normal & Normal \\
\hline
\end{tabular}

Tabel 4 menunjukkan bahwa nilai $\chi^{2}$ hitung sebelum dilakukan perlakuan (pretes) adalah 3,29 kurang dari $\chi 2_{\text {tabel }} 9,488$ dan nilai $\chi^{2}$ hitung sesudah perlakuan (postes) adalah 4,68 kurang dari $\chi_{\text {tabel }}^{2} 9,488$, artinya data berdistribusi normal.

Selanjutnya dilakukan pengujian hipotesis menggunakan t-test. Data hasil perhitungan ditunjukkan oleh tabel 5 .

Tabel 5. Hasil Uji Hipotesis

\begin{tabular}{l|c|c|c|c}
\hline Pengujian & $\mathbf{N}$ & $\mathbf{D k}$ & $\mathbf{t}_{\text {hitung }}$ & $\mathbf{t}_{\text {tabel }}$ \\
\hline Pretes & 13 & \multirow{2}{*}{12} & 7,27 & 1,78229 \\
\cline { 1 - 2 } Postes & 13 & & & \\
\hline
\end{tabular}

Tabel 5 menunjukkan bahwa $t_{\text {hitung }}=7,27$ dimana $\mathrm{dk}=\mathrm{n}-1=12$ dengan taraf signifikan 0,05 diperoleh $t_{\text {tabel }}=1,78229$. Dari data tersebut dapat diketahui bahwa $t_{\text {hitung }}>t_{\text {tabel }}$ sehingga $\mathrm{H}_{0}$ ditolak dan $\mathrm{H}_{\mathrm{a}}$ diterima. Artinya terdapat pengaruh penerapan model pembelajaran CTL berbantuan TTS terhadap hasil belajar.

Hal ini sejalan dengan penelitian yang dilakukan Asmaningrum (2017) bahwa penggunaan media TTS pada model pembelajaran kooperatif SGD lebih efektif 
untuk meningkatkan hasil belajar mahasiswa Jurusan Teknik Sipil Semester I Tahun Ajaran 2016/2017 dibanding media LKM pada materi Perkembangan Teori Atom.

Peningkatan ketuntasan hasil belajar mahasiswa pada model CTL karena diberi kesempatan untuk berusaha menyelesaikan masalah secara individu. Mahasiswa diwajibkan mengevaluasi materi tentang hal-hal yang belum dipahami untuk ditanyakan pada anggota kelompoknya yang sudah paham saat evaluasi berlangsung. Hal ini menyebabkan seluruh mahasiswa lebih mudah paham tentang materi.

Pada penerapan model pembelajaran CTL berbantuan TTS mahasiswa yang tidak tuntas sebanyak 4 orang. Pemecahan masalah pada mahasiswa dilakukan secara individu terlebih dahulu, apabila ada masalah yang tidak diketahui akan dibawa kedalam diskusi. Mahasiswa dilatih untuk berani mengemukakan pendapat dalam diskusi kelompok. Sehingga akan lebih aktif dalam diskusi. Jika ada suatu hal yang kurang atau terdapat kesalahan dapat dikoreksi maupun ditambahkan. Seluruh mahasiswa diberi tanggung jawab yang sama dalam menyelesaikan permasalahan dan diberikan kesempatan untuk berpikir secara mandiri sebelum bertukar pendapat. Sehingga mahasiswa memiliki waktu yang lebih banyak berpikir dan berkomunikasi dengan teman, pendidik bahkan diri mereka sendiri yang membuat mahasiswa lebih aktif karena keingintahuan mereka semakin meningkat. Dalam proses pembelajaran mahasiswa berani bertanya apabila ada permasalahan yang kurang dipahami, sehingga dalam hal ini pendidik lebih mudah dalam memantau perkembangan proses belajar mahasiswa.

Menurut Rohwati (2012) hasil belajar merupakan hal yang penting yang dijadikan tolak ukur keberhasilan siswa dalam belajar dan sejauh mana sistem pembelajaran yang diberikan guru berhasil atau tidak. Suatu belajar mengajar dikatakan berhasil apabila kompetensi dasar yang diinginkan tercapai.

\section{KESIMPULAN}

Berdasarkan hasil penelitian dan pembahasan, dapat disimpulkan bahwa terdapat pengaruh penerapan model pembelajaran CTL berbantuan TTS terhadapa hasil belajar kimia mahasiswa, yang dibuktikan dengan uji hipotesis sampel $\mathrm{t}$-test yaitu data $\mathrm{t}_{\text {hitung }}>\mathrm{t}_{\text {tabel }}(7,27>$ 1,78229) menunjukkan bahwa $\mathrm{H}_{0}$ ditolak dan $\mathrm{H}_{\mathrm{a}}$ diterima. Dengan demikian dapat dikatakan bahwa model pembelajaran CTL berbantuan Teka-Teki Silang (TTS) dapat digunakan untuk meningkatkan hasil belajar kimia mahasiswa.

\section{DAFTAR RUJUKAN}

Asmaningrum, H. P. (2017). Studi Komparasi Hasil Belajar Kimia Menggunakan Merdia LKM dan TTS melalui Implementasi Model Pembelajaran Kooperatif Small Group Discussion (SGD). Jurnal Tadris Kimia, 99.

Claire, E. (2010). Easy English Crossword Puzzle. United States of America: Eardley Publications Saddle Brook.

Isjoni. (2007). Coopetative Learning Efektivitas Pembelajaran Kelompok. Bandung: Alfabeta.

Prasetyaningrum, D. (2013). Studi Komparasi Metode Pembelajaran Teams Games Tournament(TGT) Di Sertai Kartu Soal dan Roda Impian Terhadap Prestasi Belajar Siswa Pada Materi Hidrokarbon Kelas X SMA Negeri 7 Surakarta Tahun Pelajaran 2012/2013. Jurnal Pendidikan Kimia Vol. 2 no. 3,123 .

Purnamasari, Y. (2013). Pengaruh Model Pembelajaran Kooperatif Tipe Teams Games Tournament(TGT) Terhadap Kemandirian Belajar Dan Peningkatan Kemampuan Penalaran Dan Koneksi Matematik Peserta Didik SMPN 1 Kota Tasikmalaya. Jakarta.

Purwanto, N. (2010). Psikologi Pendidikan. Bandung: PT. Remaja Rosdakarya.

Rohwati, M. (2012). Penggunaan Education Game Untuk Meningkatkan Hasil Belajar IPA Biologi Konsep Klasifikasi Mahluk Hidup. Jurnal Pendidikan IPA Indonesia.

Rusman. (2011). Model-Model Pembelajaran: Mengembangkan Profesionalisme Guru. Jakarta: Rajawali Pers.

Sanjaya, W. (2010). Strategi Pembelajaran Berorientasi Standar Proses Pendidikan. Jakarta: Kencana.

Sugiyono. (2016). Metode Penelitian Kuantitatif, Kualitataif, dan R\&D. Bandung: Alfabeta.

Suharsaputra, U. (2014). Metode Penelitian Kuantitatif, Kualitatif, dan Tindakan. Bandung: PT. Refika Aditama.

Umar, H. K. (2013). Meningkatkan Hasil Belajar Siswa Melalui Penggunaan Model Pembelajaran Kooperatif Tipe Number Heads Together Pada Mata Pelajaran Ekonomi Kelas XA SMA Negeri 2 Gorontalo. Jurnal Penelitian, 1. 